\title{
"[...] nawet zabić się nie mogę, bo chcę widzieć”. O spojrzeniu przez ,Łzy"
}

Beata Łazarz 


\section{"[...] nawet zabić się nie mogę, bo chcę widzieć". O spojrzeniu przez Łzy}

Beata Łazarz
Pierwszy zarys artykułu zostałprzedstawiony na kursie IBL PAN „Literatura i psychoanaliza" (poziom III), prowadzonym przez prof. dr hab. Danutę Danek.

TEKSTY DRUGIE 2017, NR 5, S. 301-312

DOI: $10.18318 /$ td.2017.5.20

$\boldsymbol{七}^{2}$ zy Grzegorza Strumyka' to nie tylko powieść o wielkiej wartości literackiej, lecz także powieść niezwykła ze względu na sposób operowania obrazami. Autor wręcz maluje słowami, z ogromną przenikliwością oddając świat psychiki bohaterów, w którym kształty i barwy nabierają symbolicznych znaczeń.

Związki między malarstwem i literaturą mają długą tradycję. Pierwszym, który odkrył istnienie między nimi ścisłej relacji, był zapewne Symonides z Keos (VI-V wiek p.n.e.). To właśnie jemu przypisuje się twierdzenie, że malarstwo to milcząca poezja, a poezja - mówiące malarstwo. Poezja jest jak obraz, ale i obraz jest jak poezja: sztuki te różni jedynie obecność (lub brak) słowa. We Łzach poetycka proza i obrazy wywoływane w wyobraźni czytelników nie tylko dopełniają się i zastępują nawzajem, lecz w niezwykły sposób przenikają i splatają ze

1 G. Strumyk $Ł z y$, W.A.B., Warszawa 2000. Podawane dalej w tekście przy cytatach liczby w nawiasach kwadratowych wskazują stronice tego tomu.
Beata Łazarz - dr, W 2015 roku obroniła W Instytucie Sztuki PAN rozprawę doktorską Płeć przerażającego. Wizerunki terrorystekw sztukach plastycznych.Zajmuje się antropologią kultury wizualnej, psychoanalizą oraz związkami teologii i sztuki. 
sobą, tworząc gęstą tkankę opowieści o parze bezdomnych, ich przeżyciach i emocjach.

Poranieni przez najbliższych, bohaterowie Strumyka patrzą niemal dosłownie przez pryzmat bólu. Rzeczywistość jawi się im jako świat „na opak”, naznaczony brakiem nadziei, rozpadem i śmiercią. Już na samym początku powieści pojawia się obraz podartych na kawałki reklam, destrukcji iluzorycznej wizji idealnego świata. „Pozrywane, wielkie, kolorowe usta, oczy. Wszystkim dobrze na tych plakatach. Zostały strzępy. [...] Mroźny wiatr wzbijał papiery w górę. Siekane deszczem, rozmiękły, wiatr je zrywał. Przelatywały nad głowami: oczy, kolana, oddzielnie piersi, papierosy, samochody, dymek" [s. 5].To, co miało jawić się jako doskonałe i bez skazy, ulega bezlitosnej degradacji. Rozpad nie dotyczy tylko wymiaru materialnego; rozpadają się także kategorie logiczne, porządkujące postrzeganie rzeczywistości. Jest to świat, w którym samotne staruszki rodzą dzieci, a wózek dziecinny służy jako karawan pogrzebowy dla psa; ludzie zachowują się jak psy, a pies-Facet jest z nich najbardziej ludzki; pijani są trzeźwi, a trzeźwi „pijani do nieprzytomności" [s. 55]. Towarzyszka, przyjaciółka i być może ukochana Gabriela, głównego bohatera, jest jak chłopiec czy też jest chłopcem, nie przestając przy tym być kobietą. Zaciera się nawet podział na ludzkie - zwierzęce. Z psem-Facetem utożsamiany jest momentami zarówno bohater, jak i bezimienna dziewczyna; zwierzę stanowi także ważny łącznik między nimi, jak dziecko. Byli jak „zmęczone psy, pies między nimi” [s. 17]. W ostatecznym wymiarze rozpada się czas, przestrzeń i podmiotowość. Z tego, co istniało i wydawało się trwałe, pozostały „Strzępy. Półpłynne. Trafiały się odcinki czasu, jeśli już przyjąć geometrię, że nic nie chroniło, żaden porządek wymyślony, by zrozumieć, budować, żyć dalej. [...] Czas się nie liczył" [s. 97].

Rozpadowi świata towarzyszy rozpad języka. Zapamiętane zostały złe słowa, które zyskały niemal niesamowitą ${ }^{2}$ moc sprawczą. „Od przekleństw na języku wyrośnie żałoba. Słowa i przestrogi z dzieciństwa się sprawdzą” [s. 127-128]. Natomiast dobre słowa utraciły znaczenie, stały się puste. Gabriel o swoich kolejnych, nieudanych związkach mówi: „nic mnie tak nie skazywało, jak codzienna czułość, słowa i gesty na pamięć" [s. 82]. Bezdomnym bohaterom mówienie przychodzi z wyraźnym trudem, nie potrafią wyrażać uczuć ani komunikować się ze sobą. Gabriel nie chce mówić; chłopięca dziewczyna "mówi jeszcze mniej od niego, a wszystko, o czym nie mówi, widać po niej,

2 S. Freud Niesamowite, w: tegoż Pisma psychologiczne, przeł. R. Reszke, KR, Warszawa 1997, S. $251,258$. 
aż boli, że człowiek nie może milczeć" [s. 9]. Słowa obciążone nadmiernym ciężarem znaczeniowym lub zupełnie go pozbawione nie tylko nie odpowiadają rzeczywistości, lecz wręcz wprowadzają do niej zaburzające dysonanse.

Zawodzą także gesty, naznaczone przymusem powtarzania agresywnych i raniących zachowań zapamiętanych z dzieciństwa. Kiedy Gabriel przytulił do siebie dziewczynę, ,"wbił palce w ramię. Musiało ją zaboleć” [s. 89]. Powtórzył tym samym doświadczenie własne i jej, gdy matka „chciała dotknąć lekko, ale inaczej jej wyszło, popchnęła ją silnie" [s. 14].

Korzenie cierpienia bohaterów tkwią i w ich dzieciństwie, obciążonym brakiem miłości rodziców, i w doświadczeniach młodzieńczych, rozczarowaniach w pierwszych poważnych związkach. Ich los jest spełnieniem swoistych klątw, przekleństw rodziców i najbliższych, kochanych ludzi. Niekoniecznie przekleństw jako złych życzeń; raczej przekleństw jako niezdolności do szczęścia i miłości, mimowolnie przekazywanych z pokolenia na pokolenie, w łańcuchu toksycznego dziedzictwa ${ }^{3}$. Dom staje się przez to miejscem, które "rodzice często jak mordercy zapełniają [...] swoimi ofiarami” [s. 9]. Ma to odcień przymusu, jakiegoś fatum, od którego nie ma ucieczki, nawet jeśli świadomie dąży się do czegoś przeciwnego. Zdaje sobie z tego sprawę matka Gabriela, gdy zrozpaczona pyta: „Czy jego życie musi być dalszym ciągiem mojego cierpienia? Czy tak musi być? Myślałam, że choć jego życie szczęśliwe będzie moją nagrodą" [s. 68]. Życie i tożsamość Gabriela ostatecznie rozpadły się, kiedy został wyrzucony z domu przez kobietę.

$\mathrm{Na}$ losie Gabriela szczególnie zaważyła relacja z jego przyjacielem z lat szkolnych, Adamem. W powieści wyraźne jest zatarcie granic między nimi, przenikanie się ich postaci, sugerujące ich utożsamienie. Adam to przyjaciel z dzieciństwa, który po przeżyciu nieszczęśliwej miłości nie zdołał odzyskać równowagi i - po nieudanej próbie powrotu do normalnego życia - kilkadziesiąt lat później popełnił samobójstwo. Moment zerwania z ukochaną nastąpił na cmentarzu; dziewczyna, jeszcze niegotowa czy też całkowicie niezdolna do przyjęcia jego desperackiej miłości, skazała go tym samym na śmierć, nieodwołalną, choć odległą w czasie. Kiedy wyjeżdżał, by odbyć służbę wojskową w innym mieście i żegnał się z Beatą, był „wmurowany w okno pociągu. Razem z cmentarzem i całym jego inwentarzem żywym. Nieżywy" [s. 56]. Po upływie dwudziestu lat jeszcze o niej nie zapomniał i wciąż ją rozpaczliwie kochał; być może właśnie dlatego, że ta miłość była tak beznadziejna.

3 Por. A. Miller Pamięć wyzwolona: jak przerwać łańcuch toksycznego dziedzictwa, przeł. J. Hockuba, Jacek Santorski \& CO Agencja Wydawnicza, Warszawa 1995. 
Doprowadziła go do samobójstwa. Gabriel był alter ego Adama, jego niesamowitym - mówiąc językiem Zygmunta Freuda - sobowtórem ${ }^{4}$, potrzebnym, by za niego wyrażać miłość do Beaty; jednocześnie Gabrielowi Adam „z tym porażeniem, miłością czy śmiercią, był [...] jeszcze bardziej potrzebny. Oboje byli. Żył we mnie, choć to nie jest możliwe, dopiero czekam na życie” [s. 43]. Bohater „od zawsze i przy nich" miał "szansę samotnej śmierci” [s. 83]. Owo ontologiczne splątanie Gabriela i Adama wprowadza w powieści niepewność, która z tych postaci jest żywa, a która martwa; być może w pewnym wymiarze obaj są martwi. Niemożność pogodzenia się ze śmiercią Adama stała się dla Gabriela przyczyną Freudowskiej melancholii, tej reakcji na utratę kogoś bliskiego, która nie pozwala jej przeboleć ani zapomnieć, prowadząc do utraty samego siebie. Było to doświadczenie, które zamknęło bohatera „w lustrzanej intersubiektywności, w identyfikacji z utraconym obiektem”. Poddał się działaniu popędu śmierci poprzez identyfikację z przyjacielem, który zginął samobójczą śmiercią i jednoczesne kierowanie agresji przeciwko sobie, nie kończące się dręczenie samego siebie. Zarazem zmarły przyjaciel stał się niewyrażalny, niemożliwy do wypowiedzenia słowami.

Jako podstawowy środek wyrazu, dostępny dla bohaterów, pozostały obrazy: jednak „Były to obrazy szczelnie wypełniające myśli, z których nic nie pozostawało poza bólem” [s. 97]. Jak zauważył autor Objaśniania marzeń sennych, to, co obrazowe, jest "czymś zdatnym do przedstawienia", a dzięki temu $\mathrm{w}$ wielu przypadkach mogą stać się konkretyzacją nieuświadamianych myśli łatwiej niż słowa. W szczególności wspomnienia traumatyczne często są kodowane raczej w formie wyrazistych wrażeń i obrazów niż zwerbalizowanych, linearnych narracji, które można włączyć do zachowującej ciągłość historii życia ${ }^{7}$. Myśli wyrażone w obrazach łatwiej znajdują drogę do świadomości, a jednocześnie obrazy stwarzają większe możliwości tworzenia różnorodnych relacji, skojarzeń i powiązań niż abstrakcyjne terminy.

Celem obrazów kreowanych w powieści nie jest oddanie realistycznego oglądu rzeczywistości, lecz emocji i przeżyć bohaterów. Zdają się tym samym

4 S. Freud Niesamowite, s. 247.

5 K. Bojarska Żałoba i melancholia w Tworkach, w: Freud i nowoczesność, red. Z. Rosińska, J. Michalik, P. Bursztyka, Universitas, Kraków 2008, s. 223.

6 S. Freud Objaśnianie marzeń sennych, przeł. R. Reszke, KR, Warszawa 2007, s. 292; wyróżnienie w tekście za oryginałem.

7 J.L. Herman Przemoc. Uraz psychiczny i powrót do równowagi, przeł. A. Kacmajor, M. Kacmajor, Gdańskie Wydawnictwo Psychologiczne, Gdańsk 2004, s. 48-49. 
stanowić doskonałą realizację wezwania, by w sztuce „Nie od t wa r z a ć więcej natury i życia przy pomocy przybliżonego prawdopodobieństwa lub improwizowanego złudzenia wzrokowego, ale, przeciwnie, odtwarzać nasze wzruszenia i marzenia, pr zed sta wi a ją c je przy pomocy harmonijnych form i kolorów"8. Dzięki odejściu od mimetycznego naśladowania rzeczywistości i skupieniu uwagi na wzruszeniach i marzeniach w obrazach mogą swobodnie dochodzić do głosu nie tylko uświadamiane przeżycia, lecz także treści nieświadome. Wtedy obrazy stają się podatne na badanie za pomocą narzędzi psychoanalizy, a estetyka może stać się nauką „o cechach naszego czucia".

Z perspektywy psychoanalizy szczególnej uwagi wymaga sposób, w jaki autor powieści symbolicznie wykorzystuje kształty i barwy. Szczególnie ważną rolę odgrywają te elementy i środki wyrazu, które odnoszą się do popędu śmierci i popędu życia. Z tego względu ważnym symbolem w świecie $Ł e z$ jest kształt prostokąta, zwłaszcza w powiązaniu z achromatyczną szarością. Jest on kojarzony z kształtem budynku, który może stać się czyimś domem, a przez to - w oczach bezdomnych - zawiera już w sobie zapowiedź rozpadu. Kąty proste w konfrontacji i z naturą, i z życiem okazują się nietrwałe. Prostokąt - nie bez powodu kojarzący się z kształtem nagrobka - w tym tekście zdaje się symbolizować popęd śmierci, dążenie do cofnięcia się życia do stanu nieorganicznego ${ }^{10}$, a więc także skłonności samobójczych, odczuwanych zwłaszcza przez Gabriela; jako upostaciowanie bezruchu, sztywności i martwoty stanowi przeciwieństwo życia, które jest ruchem, zmianą i rozwojem.

Od obrazu prostokątów uwalnia, paradoksalnie, patrzenie przez łzy. Kiedy obraz zaczyna falować, „mniej widać prostokątów potrzebnych do budowy domów. Skazanych na rozsypkę. Przez łzy nie widać kątów prostych, [...] Taki ładny dzień. [...] To dopiero początek dnia, dzień krótki, ale światło ciepłe buduje nowe przestrzenie, figury dalekie od prostokątów" [s. 40]. Łzy, stanowiące wyraz bólu - a więc efekt przełamania stanu emocjonalnego zamrożenia - pozwalają się od niego uwolnić. Zaburzają widzenie, zacierają kształty, a przez to pozwalają inaczej patrzeć i dostrzec coś odmiennego. Dopiero po tym doświadczeniu mogą pojawić się słowa i otwiera się możliwość

8 M. Denis Od Gauguina i van Gogha do klasycyzmu, przeł. H. Morawska, w: Artyści o sztuce. Od van Gogha do Picassa, oprac. E. Grabska, H. Morawska, PWN, Warszawa 1977, do s. 88.

9 S. Freud Niesamowite, s. 235.

10 S. Freud Poza zasadą rozkoszy, w: tegoż Psychologia nieświadomości, przeł. R. Reszke, KR, Warszawa 2009, s. 191, 197. 
zmiany także w życiu: „- Moglibyśmy inaczej żyć - powiedział przez łzy” [s. 53]. Prostokąt może zostać przełamany nie tylko przez łzy, lecz także przez uśmiech. Zaskakująco pełen nadziei jest obraz, który dziewczyna widywała w dzieciństwie przed snem: „Jasny prostokąt zjawiał się na powierzchni kaflowego pieca, błyszczał. Wokół wszystko ciemniało, stawało się niewidoczne. Pęknięcie przez środek prostokąta (kafla?) zamieniało się w uśmiech" [s. 16].

Skostnienie i chłód konotują w tekście również wszelkie ostro zarysowane kształty, które jednak nie zastygają na zawsze, lecz są skazane na rozsypanie się lub roztopienie w coś lepkiego. „W dole na placu kałuże z suchymi liśćmi zamarzły. Na podjeździe do ogrodzenia ani śladu czyjejś obecności. Zamarznięte w błocie ich własne ślady, pokryte szronem. Grafiki" [s. 37]. Wraz z nadejściem cieplejszych dni te grafiki nieuchronnie obrócą się w pył lub błoto. Jednak graficzne kształty, podobnie jak prostokąt, nabierają życia, kiedy uwolnione zostają emocje, jak np. w scenie wchodzenia po schodach, oświetlonych światłem świeczki. Bohaterowie „Wspinali się w górę. Z cieniami. Na szarych ścianach poruszały się bezszelestnie.

- Jestem narysowana - odezwała się dziewczyna. - Z tobą" [s. 32].

Wyraźne jest tu nawiązanie do postaci korynckiej dziewczyny, obrysowującej cień opuszczającego ją kochanka". Cień-rysunek idących razem postaci Gabriela i dziewczyny staje się znakiem miłości, a związek tej sceny z legendą o początkach malarstwa sugeruje, że achromatyczny szkic może wypełnić się grą barw.

Przeciwieństwem geometrycznego kształtu prostokąta jest pies-Facet, w niemal doskonały sposób wcielający popęd życia. Dla bohaterów był on kimś więcej niż psem, przyjacielem czy nawet zastępczym dzieckiem. Stanowił szczekający, machający ogonem i mieniący się kolorami dowód na to, że możliwa jest radość i szczęście m i mo nieszczęść, bólu, głodu i chłodu. W jego doświadczeniu życie było czymś, co dzieje się samo, po prostu się wydarza: psu „się żyje” [s. 27]. Pod koniec powieści bohater stwierdza, że każdy ma bezwarunkowe prawo, by żyć, nie mi mo kolejnych zawodów i rozczarowań, ale właśnie d l a t e g o: „Im mniej się z życia ma, tym bardziej to życie się należy. Po prostu należy" [s. 129]. Jeśli się na nie otworzyć, niesie ze sobą cierpienie i ból, ale i szansę na szczęście i miłość.

Śmierć psa była dla bohaterów bolesną stratą, która jednak dała im szansę na zmianę patologicznych wzorców przeżywania i postępowania. Chyba po raz pierwszy udało im się przeżyć po nim żałobę, rozpoznać stratę

11 Pliniusz Starszy Historia naturalna, XXXV, §16, 151. 
i ją przezwyciężyć. Jak podkreślał ojciec psychoanalizy, pomyślne przejście przez proces żałoby prowadzi do reintegracji „ja” żałobnika i pogodzenia się ze zmienionym kształtem świata. "Ja” "po przeprowadzeniu pracy żałoby, jest na powrót wolne i nie zahamowane"12. Do pracy żałoby wyraźnie odnosi się sen Gabriela, w którym złoty Pies w niebieskim płaszczu i on - jego Pan, od zawsze tworzący "nierozdzielną parę rozumiejących się istot, grających kolorów" [s. 110], znowu się pojawili po długiej nieobecności: Pan pchał przed sobą czarny wózek ze sparaliżowanym Psem. Przywołana została tu scena pogrzebu Faceta (wożenie jego zwłok po mieście w dziecinnym wózku), ale zarazem została przekroczona - pies nie odszedł ostatecznie, dopóki oni o nim pamiętają, nawet jako o niedoskonałej, śmiertelnej istocie. Wspomnienie o nim nie zostało wyparte, lecz zapamiętane jako obraz: złotożółtego psa i Pana w błękitnym płaszczu, doskonale dopełniających się dwóch istot i dwóch barw, tworzących razem harmonię.

Kluczowe znaczenie dla zrozumienia symbolicznego świata bohaterów ma poszukiwanie równowagi między właśnie tymi dwoma kolorami komplementarnymi w stosunku do siebie: żółcią i błękitem. Johann Wolfgang von Goethe uważał je za barwy fundamentalne, a zarazem przeciwstawne, gdyż w jego ujęciu błękit jest najbliższy ciemności, a żółty - jasności. Powoduje to, że skrajnie odmiennie oddziałują na emocje i przeżycia człowieka czy też używając sformułowania samego Goethego - mają odmienne działanie zmysłowo-etyczne. Punktem wyjścia jest fakt, że poszczególne barwy wywołują określone nastroje: barwa żółta „ma zawsze cechy jasności i posiada pogodne, rozweselające, łagodnie pobudzające właściwości” ${ }^{\prime \prime 3}$, natomiast błękit „wywołuje w nas uczucie chłodu, tak jak przypomina nam również cień"14; przy tym „należy do strony negatywnej i w swej najczystszej postaci jest niejako nicością, która pobudza"15. Ich połączenie tworzy harmonię, która zyskuje wymiar wręcz metafizyczny ${ }^{16}$.

W świecie tworzonym przez Strumyka niebieski, kolor zimna, zmierza poprzez odcienie granatu - w stronę czerni symbolizującej rozpad i śmierć,

12 S. Freud Żałoba i melancholia, w: tegoż Psychologia nieświadomości, s. 148.

13 J.W. Goethe Nauka o barwach, przeł. E. Namowicz, w: tegoż Wybór pism estetycznych, oprac. T. Namowicz, PWN, Warszawa 1981, s. 296.

14 Tamże, s. 300.

15 Tamże, s. 299.

16 Tamże, s. 324. 
lecz także kojarzy się z niebem w pogodny letni dzień. Żółty używany jest do oddania odczucia fizycznego rozpadu; zwłaszcza w ciemnych i ziemistych odcieniach jawi się jako barwa brudu, zaniedbania (żółte zęby i pożółkła skóra), choroby (wymiociny), lepkości (rozmiękły tytoń), lecz również konotuje słońce, światło i ciepło. Szczególnie wyraziste są zmiany znaczenia żółci w zestawieniu obrazów tygrysiego oka, „uwięzionego światła” [s. 79] i wymiotów. Już Goethe zauważył, że „przez nieznaczne i niedostrzegalne posunięcie odczuwamy teraz to, co robiło wspaniałe wrażenie ognia i złota, jako plugawe; barwa chwały i rozkoszy zostaje zamieniona w barwę hańby, wstrętu, niesmaku"17. Zabrudzenie żółci, przypisanie jej do czegoś lepkiego, powodowało, że traciła ona swoją jasność, możliwość pozytywnego oddziaływania. Kiedy chora dziewczyna wymiotowała, „nitki żółtej śliny ciągnęły się... [...] Wkoło mokro, wodniste, żółto brązowe plamy na białej, wypchanej powłoce" [s. 87]. Niemal kwintesencja rozpadu i odrażającego brudu. Jednak możliwy jest także proces odwrotny, oczyszczenie żółci i przywrócenie jej świetlistości. Symbolem tej możliwości w powieści stało się żółto-czarne tygrysie oko, kupione dla dziewczyny przez Gabriela w indyjskim sklepie, do którego przyciągnęła go żółto-niebieska wystawa. Jako dar czułości i troski wyrażał możliwość przejścia od trywialnych, bolesnych doświadczeń do bliskości i szczęścia.

Przy pomocy owych dwóch barw opisywane są kluczowe postaci towarzyszące bohaterowi. Osiagnięcie pełnej harmonii kolorystycznej sugerowane jest w szczególności w opisach psa. Facet był w rzeczywistości czarnorudy, jednak w oczach Gabriela jawił się jako żółto-złoty z niebieskimi oczami, nabierając cech postaci z innego wymiaru. „W górze jasnożółty, jak złoto, pies patrzył niebieskimi oczami. [...] Pies był dokładnie nad nimi, przyglądał się w napięciu. Złote włosy rozdzielały błękit" [s. 29]. W tych samych barwach jawi się ktoś (Bóg? Anioł Stróż? Uniwersalna Miłość?), kto z góry spogląda na bohaterów, dając im otuchę i nadzieję, jak w wizji Gabriela: „Błękit gotował się od jasnego złota. Łączyły się, ale nie mieszały. Koło w kole, bez linii podziału. Głowa lekka i ciepła. Świecąca kula. [...] Ziarno spoglądało ukrytym okiem. Wypatrzyło ich" [s. 8]. To oko zdawało się towarzyszyć na co dzień bohaterom także poprzez spojrzenie psa, który patrzył niebieskimi oczami „łagodnie, bez śladu lęku, patrzył rozumnie. Oczy rozumiały najwięcej. [...] Chciał gwizdnąć na próbę, czy jest prawdziwym psem. Nie zrobił tego. Zwracał się do tych oczu. Był w nich spokój” [s. 53]. 
W przypadku, gdy żółty i błękitny pozostają ze sobą w równowadze, stają się barwami raju, jak we wspomnieniu brzegu jeziora latem czy na obrazku przedstawiającym Anioła przeprowadzającego dzieci nad przepaścią. Kontrast tworzący harmonijną całość jest przeciwieństwem rozpadającego się świata. Na poziomie fizycznym to zestawienie kolorystyczne kojarzy się ze słońcem, otwartą przestrzenią i ciepłem. Nie przypadkiem barwy te powracają w opisie łaźni.

Nieharmonijne połączenie żółcienia i błękitu, w szczególności wprowadzenie ciemnych odcieni niebieskiego, sugeruje powiązanie z ciemnością, zmierzaniem w stronę śmierci. Jednak dodanie jasnego odcienia żółtego daje efekt przeciwstawienia światła i ciemności. W jednym z opisów bezimienna dziewczyna pojawia się w migawkowym ujęciu: „Krótkie, jasnożółte włosy na tle granatowoszarej ściany" [s. 41], stając się niemal symbolem owego światła; obejmuje ono tylko niewielki fragment jej postaci, ale jednak powoduje, że wyraziście odznacza się ona od ciemnego, przytłaczającego tła, a zatem być może zdoła się z niego wyrwać.

Drugi kluczowy dla zrozumienia symbolicznego świata bohaterów zestaw barw to biel, czerń i czerwień. Na początku powieści pojawia się obraz śladów krwi na śniegu; ich pochodzenie nie jest znane, lecz migawkowy obraz czerwonych plam został powiązany z sugestią śmierci pary bezdomnych z zimna, nie tylko fizycznego, lecz także psychicznego; śmierci, po której latem „wyjdzie pustka, puste miejsca po nich" [s. 19-20]. Barwy achromatyczne wyraźnie odnoszą się do śmierci. Jednak niejednoznaczne pozostaje znaczenie czerwieni. Jest ona kolorem krwi i ciepła. Krew jest kojarzona z życiem, ale jej rozlew konotuje śmierć; zastygające na mrozie krople krwi to czerwień zmierzająca ku czerni. Jako kolor ciepła jest wielokrotnie kontrastowana $\mathrm{z}$ niebieskim symbolizującym $\mathrm{w}$ tym zestawieniu zimno: $\mathrm{np}$. $\mathrm{w}$ ten sposób zostały oddane ambiwalentne odczucia bohatera w stosunku do matki: wzięty od niej niebieski termos w czerwone różyczki oddawał także „ciepło i chłód skóry starej matki” [s. 66]. Jednak czerwień jest także kolorem dynamicznym, wprowadzającym przemianę, na złe, np. kiedy jako zabarwienie nieba zapowiadała większy mróz, lub na dobre, gdy w podczas wizyty w łaźni „w słabo oświetlonym korytarzu, choć nie było czerwieni, raczej brąz drewna, płynęła skądś czerwień. Jak woda, jej szum, pluskanie zza drzwi" [s. 122].

W zakończeniu Łez powraca obraz krwi rozlanej na stwardniałym śniegu. Jednak coś się zmieniło. „Po kilkudziesięciu metrach natknęli się na skorupę jeża. Leżała odwrócona do góry wyjedzonym środkiem. Pusta. [...] 
- Ja już kiedyś musiałem to widzieć... Pamiętam.

- Nie pamiętaj - usłyszał" [s. 132].

Chwilę później Gabriel „zobaczył mężczyznę powieszonego na rurze ciepłowniczej biegnącej nad ziemią" [s. 133]. Ten obraz stanowi ewokację śmierci Adama, jego przyjaciela od lat szkolnych, a zapewne także jego własnych pragnień samobójczych.

To, że Gabriel zobaczył obrazy śmierci, a następnie razem z dziewczyną, minął je, może sugerować, że dokonał wyboru, by żyć, a tym samym rozwiązał konflikt, który przez lata określał jego życie, albo przynajmniej odnalazł drogę do jego rozwiązania. Pusta skorupa jeża odnosiła się także do jego własnej śmierci wewnętrznej, owego „pustego miejsca po nim”; dostrzeżenie jej, ujęcie w formie obrazu, umożliwiło konfrontację z postacią zmarłego przyjaciela - jak można przypuszczać - wcześniej głęboko wypartą. Powrót traumatycznego wspomnienia i odczucie bólu, wyrażone przez łzy, stanowi podstawowy warunek przepracowania go i odzyskania równowagi.

W tym procesie obrazy odgrywają równie ważną rolę jak słowa; oba te sposoby komunikowania się, ikoniczny i werbalny, dopełniają się i wzajemnie wzmacniają. W procesie psychoterapii „narracja bez traumatycznych obrazów i wrażeń cielesnych jest ogołocona i niekompletna. Ostatecznym celem jest jednak ujęcie w słowa całej historii, łącznie z obrazami"18. Obrazy, wrażenia i słowa muszą złożyć się na uporządkowaną opowieść, umiejscowioną w czasie i przestrzeni. Nie jest to proste: Gabriel dopiero musi szukać słów, by „od początku nazywać nazwane wcześniej ludzkie rzeczy, które często już prawie tylko widzi" [s. 9]. Jednak opowiedzenie chłopięcej dziewczynie historii Adama, przełamanie jej niewyrażalności, przekazanie jej drugiej osobie za pośrednictwem słów i obrazów otworzyło możliwość przerwania zabójczego oddziaływania melancholii. W ten sposób został zapoczątkowany ozdrowieńczy proces: po rozmowie ona także doświadczyła powrotu wypartych treści: „zasypiała, ale widziała, nie przestawała widzieć” [s. 84]. Wróciły jej własne bolesne wspomnienia, obrazy, których nie potrafiła jeszcze wyrazić słowami. Jednak odreagowała je, odegrała swój ból atakiem choroby i silnymi wymiotami ${ }^{19}$, budząc współczucie Gabriela.

Po śmierci psa-Faceta i odbyciu żałoby po nim pozbawiony domu bohater po raz pierwszy poczuł potrzebę ciepła, zrobienia czegoś dla siebie i dla swojej

J.L. Herman Przemoc..., s. 187.

19 S. Freud Przypominanie, powtarzanie, przepracowywanie, w: tegoż Technika terapii, przeł. R. Reszke, KR, Warszawa 2007, s. 169. 
towarzyszki. Podjął decyzję o pójściu do łaźni; w odpowiedzi dziewczyna zaczęła mówić o swoich pragnieniach, „o wszystkim, czego nie przeżyła; o słońcu, o wodzie, o trawie, że położyłaby się na wodzie w jeziorze, wieczorem, gdy woda jest ciepła, powietrze letnie, stygnie upalny dzień" [s. 111]. Troska mężczyzny uwolniła w młodej kobiecie pragnienie ciepła, można przypuszczać, że także w wymiarze emocjonalnym. Jego słowa miały moc wywoływania wyobrażenia ciepłego letniego dnia, a więc tego, w którym żółtozłota barwa słońca i błękit nieba pozostają w harmonii. Pojawił się obraz o mocy wywołania przemiany.

Wizyta w łaźni stała się przełomem, gdyż w jej trakcie Gabriel głęboko odczuł pragnienie życia i zarazem lęk przed nim. Uwolnione przez ciepło uczucia znalazły wyraz we łzach: „Płakał. Właściwie nie był to płacz. Łzy wypływały, jakby człowiek był nimi wypełniony. Na początku chciał ukryć. Później już nie, jak nie można ukryć własnego oddechu. Obrócił głowę do ściany. - Ta wanna jest pełna łez - powiedział" [s. 130]. W konsekwencji tego przeżycia jego spojrzenie zostało oczyszczone przez łzy, a to umożliwiło zobaczenie zmarłego przyjaciela i być może otworzyło drogę do przeżycia żałoby po nim.

W pewnym momencie bohater mówi: „nawet zabić się nie mogę, bo chcę widzieć" [s. 82-83]. Obrazy jawią się jako uzależniający wręcz obiekt pragnienia, ale też i szansa na przezwyciężenie negatywnych doświadczeń. Powieść w jednym ze swoich wymiarów stanowi zapis trudnej drogi do widzenia, do ponownego zobaczenia wypartych obrazów i wyrażenia ich słowami, które mogą otworzyć drogę kolejnym obrazom i związanym z nimi emocjom. Być może to, co Gabriel zobaczyt na końcu, spowoduje, że uwolni się od pragnienia samobójczej śmierci. Freud wszakże pisał: „żałoba skłania «ja» do wyrzeczenia się obiektu w taki sposób, że uznaje go za zmarłego, oferując «ja» premię w postaci pozostawania przy życiu"20. 


\section{Abstract}

\section{Beata Łazarz}

INSTITUTE OF ART OFTHE POLISH ACADEMY OF SCIENCES (WARSAW)

'I Cannot Even Kill MyselfBecause I Want to See': On Looking through Tears

Reading Grzegorz Strumyk's novel Łzy [Tears], Łazarz examines the relationship between the words and images that are called up in the reader's imagination. Reading the novel as an account of the difficult journey towards seeing, Łazarz describes how it traces a path towards a new recognition of suppressed images and towards expressing those images with words; this expression allows further images to emerge, along with their related emotions. The goal of the images that Strumyk creates is not so much a realistic description of the world but a rendering of the protagonists' emotions and experiences conscious and unconscious. Łazarz pays particular attention to the analysis of Strumyk's symbolic use of shapes and colours.

\section{Keywords}

art, the unconscious, psychoanalysis, theory of colour, Grzegorz Strumyk 